\title{
GROWTH AND PRODUCTION OF ORNAMENTAL SUNFLOWER IRRIGATED WITH DILUTIONS OF TREATED DOMESTIC SEWAGE
}

\author{
CRESCIMENTO E PRODUÇÃO DE GIRASSOL ORNAMENTAL IRRIGADO COM \\ DILUIÇÕES DE EFLUENTE DOMÉSTICO TRATADO
}

\section{Karoline Santos GONÇALVES ${ }^{1}$; Gustavo Araújo BISPO² ${ }^{2}$ Samir de Sousa BANDEIRA $^{2}$; Hans Raj GHEYI ${ }^{3}$; Vital Pedro da Silva PAZ ${ }^{3}$}

1. Pós-doutora, Programa de Pós-Graduação em Engenharia Agrícola da Universidade Federal do Recôncavo da Bahia,UFRB, Cruz das Almas, Bahia, Brasil. karolinesg@yahoo.com.br; 2. Graduando em Engenharia Sanitária e Ambiental, UFRB, Cruz das Almas, Bahia, Brasil; 3. Engenheiro Agrônomo, UFRB, Cruz das Almas, Bahia, Brasil; 4. Docente visitante, UFRB, Cruz das Almas, Bahia, Brasil; 5. Docente titular, UFRB, Cruz das Almas, Bahia, Brasil.

\begin{abstract}
The water and nutritional potential of wastewater has been frequently exploited as an alternative water source for the irrigation of crops, especially in regions affected by the scarcity of water resources. Thus, this study aimed to evaluate growth and production of ornamental sunflower (Helianthus annuus L.) cv. Anão de Jardim irrigated with different dilutions of treated domestic sewage in public-supply water. The experiment was conducted in completely randomized design with five treatments and four replicates, in a greenhouse, in the Experimental Area of the Agricultural Engineering Graduate Program of the Federal University of Recôncavo of Bahia, located in the municipality of Cruz das Almas - BA, Brazil. Treatments started seven days after transplanting of the seedlings and consisted of five dilutions of treated domestic sewage (TDS) in public-supply water (PSW) (100\% PSW - control; 25\% TDS $+75 \%$ PSW; $50 \%$ TDS + 50\% PSW; 75\% TDS + 25\% PSW and 100\% TDS). In the control treatment, plants were fertilized with $100 \%$ of the mineral fertilization recommendation, whereas plants in treatments with effluent received $50 \%$ of the nitrogen $(\mathrm{N})$ and potassium $(\mathrm{K})$ recommendation. Biometric (plant height, stem diameter, number of leaves, shoot fresh and dry matter and leaf area) and production (capitulum internal and external diameter, capitulum fresh and dry matter, beginning of flowering and full capitulum opening) indicators evaluated at harvest demonstrated that ornamental sunflower plants irrigated with 100\% TDS showed similar performance to those irrigated with PSW, which makes it possible to infer on the possibility of replacing PSW by TDS in irrigation, along with the $50 \%$ reduction in the recommendation of $\mathrm{N}$ and $\mathrm{K}$ fertilization, with no damage to the growth and production of ornamental sunflower, cv. Anão de Jardim, thus leading to the saving of good-quality water and fertilizers.
\end{abstract}

KEYWORDS: Helianthus annuus L.. Wastewater. Water resources.

\section{INTRODUCTION}

In agriculture, water is essential for crop development and production. Therefore, in areas where rainfall is scarce, it is of fundamental importance to complement irrigation. In some regions, such as the Northeast semi-arid region, where weather conditions establish a situation of scarcity of water resources due to the low rainfall levels and high evapotranspiration rates, domestic and industrial purposes are the priority in the use of water, which limits the use and expansion of irrigated agriculture. In addition to such limitation, most regions also face sanitary problems, with poor sanitation systems and sewage effluents dumped in watercourses, causing contamination of water bodies and environment.

Given this environmental degradation, especially water pollution, many studies have been carried out in Brazil to establish a sustainable management for water resources. Since irrigated agriculture is one of the most water-consuming activities and water resources are becoming increasingly scarce, wastewater utilization in agriculture and studies on defining techniques for the treatment of these waters and their subsequent use have been stimulated (CUBA et al., 2015).

The reuse of water in agriculture has increased significantly due to factors such as the increasing difficulty in identifying alternative sources of water for irrigation, the high cost of fertilizers and the treatment systems required before its discharge into receiving bodies, in addition to the guarantee of being used with minimum risks to public health and soil contamination. Therefore, water reuse represents a tool for the sustainability of water resources, applied mainly for non-potable 
purposes, such as agricultural use, promoting water savings (HESPANHOL, 2015).

The destination of wastewater for the use in agriculture is a feasible and promising alternative in various aspects, such as sanitary, economic and environmental. Furthermore, another convenience of water reuse in agriculture is the availability of nutrients that are essential for crop production. The need for fertilizers is significantly reduced, or even eliminated, with the use of wastewater in irrigation, because the effluents from conventional treatment systems have significant concentrations of nutrients that are essential to crop growth, besides the addition of organic matter, which acts as a soil conditioner, improving its water retention capacity.

Ornamental sunflower can be cultivated in any region of the country, presenting itself as an alternative for the floriculture sector, since it is a versatile and rustic crop with easy management, wide climatic adaptability, high tolerance to drought, cold and heat, and little influenced by latitude, altitude and photoperiod (ZOBIOLE et al., 2010). This crop has significant importance in the context of the exploitation of the productive potential of intensive cultivation centers of ornamental plants to improve profitability in small and medium rural areas in the Bahia state and Northeast region, which already has natural characteristics of poor treatment and reuse of domestic effluents.

In this region, studies have tried to establish sunflower cultivation practices that make its production feasible using rational and economical techniques, especially because it is a plant with high nutritional requirement. However, despite the progress achieved, specific information on crop management, including the possibility of using wastewaters, is still necessary (REBOUÇAS et al., 2010). Therefore, this study aimed to evaluate growth and production of ornamental sunflower (Helianthus annuus L.) cv. Anão de Jardim irrigated with different dilutions of treated domestic sewage in public-supply water.

\section{CONTENTS}

For this purpose an experiment was conducted in a greenhouse, in the Experimental Area of the Agricultural Engineering Graduate Program of the Federal University of Recôncavo of Bahia, located in the municipality of Cruz das Almas-BA, Brazil, (12 ${ }^{\circ} 40^{\prime} 12^{\prime \prime} \mathrm{S} ; 39^{\circ}$ 6' 7' W; altitude $220 \mathrm{~m})$. The climate of the region is classified as humid to sub-humid, with average annual rainfall of $1,143 \mathrm{~mm}$ (D'ANGIOLELLA;
CASTRO NETO; COELHO, 2000). According to Köppen's classification, the climate is of type Aw to Am, hot and humid tropical.

The experiment was conducted in a completely randomized design with five treatments, composed of dilutions of treated domestic sewage effluent with public-supply water (Table 1), and four replicates, totaling 20 experimental plots. Each experimental plot consisted of one $20-\mathrm{dm}^{3}$ plastic pot filled with cohesive Yellow Latosol with moderate A horizon, with the following chemical characteristics: $\mathrm{pH}(1: 2.5$ soil:water $)=5.0 ; \mathrm{OM}(\%)$ $=1.65$; base saturation and cation exchange capacity $\left(\mathrm{cmol}_{\mathrm{c}} \mathrm{dm}^{-3}\right)=1.54$ and $4.79 \mathrm{cmol}_{\mathrm{c}} \mathrm{kg}^{-1}$, respectively, and physical characteristics: $776 \mathrm{~g} \mathrm{~kg}^{-1}$ of total sand, $181 \mathrm{~g} \mathrm{~kg}^{-1}$ of clay and $43 \mathrm{~g} \mathrm{~kg}^{-1}$ of silt. The soil was corrected by the addition of limestone ( $0.75 \mathrm{~g} \mathrm{~kg}^{-1}$ of soil) 30 days before transplanting the seedlings and, on the day before transplanting, plants were fertilized with phosphorus $\left(300 \mathrm{mg} \mathrm{P}_{2} \mathrm{O}_{5}\right.$ $\mathrm{kg}^{-1}$ soil), using monoammonium phosphate (MAP) according to the recommendations of Novais, Neves and Barros (1991). Three seedlings of Helianthus annuus L., cv. Anão de Jardim, with two pairs of leaves, were transplanted to each pot.

Treatments started 7 days after transplanting (DAT) and consisted of irrigation with different dilutions of treated domestic sewage effluent in public-supply water and mineral fertilization with nitrogen and potassium (NK) via irrigation water, using 100 or $50 \%$ of the recommendation of Novais, Neves and Barros (1991) (Table 1). Fertilization with $\mathrm{N}$ and $\mathrm{K}\left(100\right.$ and $150 \mathrm{mg} \mathrm{K} \mathrm{K}_{2} \mathrm{O} \mathrm{kg}^{-1}$ soil, respectively) was split into three equal applications; the first one at 7 DAT and the others at 22 and 32 DAT. Each pot in the control treatment received 1.9 $\mathrm{g}$ of urea and $6.25 \mathrm{~g}$ of potassium sulfate, whereas each pot in treatments with effluent received $0.95 \mathrm{~g}$ of urea and $3.12 \mathrm{~g}$ of potassium sulfate.

Irrigation was manually performed daily using watering cans, and the applied water depth to maintain soil moisture close to field capacity was determined by the difference between the weight of each pot with soil at field capacity and its weight on the specific day of irrigation.

The first evaluation of plants was conducted at 22 DAT (15 days after applying the treatments), in one plant per pot, which was identified and analyzed for plant height $(\mathrm{PH})$, stem diameter (SD) and number of leaves (NL) every 15 days. In this first evaluation, another plant was harvested for the determination of leaf area (LA) and shoot fresh and dry matter (SFM and SDM, respectively). At 37 DAT, the second evaluation was performed in the plants identified for biometric analysis $(\mathrm{PH}, \mathrm{SD}$ and 
NL) and another plant was collected to determine LA, SFM and SDM, leaving only one plant per pot. The remaining plant was monitored to determine the beginning of flowering (BF), and the last evaluation (harvest) was performed at the full capitulum opening (FCO) observed in each plant based on the criteria of Castiglioni et al. (1997), according to which the beginning of flowering occurs in the R4 stage, characterized by the appearance of the first ligulate flowers, and the full capitulum opening occurs in the R5 stage, in which full flowering occurs when $50 \%$ of tubular flowers are open in the capitulum, releasing pollen.

Table 1. Treatments evaluated in the cultivation of ornamental sunflower (Helianthus annuus L., cv. Anão de Jardim).

\begin{tabular}{lcl}
\hline Treatments & TDS dilutions & NK fertilization \\
\hline T1 - control & $0 \%$ TDS $+100 \%$ PSW & $100 \%$ of recommendation \\
T2 & $25 \%$ TDS $+75 \%$ PSW & $50 \%$ of recommendation \\
T3 & $50 \%$ TDS $+50 \%$ PSW & $50 \%$ of recommendation \\
T4 & $75 \%$ TDS $+25 \%$ PSW & $50 \%$ of recommendation \\
T5 & $100 \%$ TDS $+0 \%$ PSW & $50 \%$ of recommendation \\
\hline
\end{tabular}

Cruz das Almas-BA, Brazil, 2016. TDS - treated domestic sewage, rich in N and K; PSW - public-supply water; NK - mineral fertilization with nitrogen and potassium. Composition of PSW and TDS was similar to that reported by Oliveira et al. (2017).

On the day of FCO, plants were harvested for the determination of biometric variables $(\mathrm{PH}, \mathrm{SD}$ and NL) and production variables (LA, SFM, SDM, capitulum internal (CID) and external diameter (CED), and capitulum fresh (CFM) and dry matter (CDM).

The results were subjected to analysis of variance by $F$ test and means were compared by Scott-Knott test at 0.05 probability level.

The results obtained showed that there was no significant effect $(p>0.05)$ of the treatments on the ornamental sunflower plants for the variables evaluated in none of the three evaluations (Table 2).

However, in the final evaluation, plants irrigated with $100 \%$ TDS and fertilized with $50 \% \mathrm{~N}$ and $\mathrm{K}$ recommendation $(50 \% \mathrm{NK})$ showed mean values of all variables superior to those of plants irrigated with TDS dilutions of 25, 50 and $75 \%$ and fertilized with $50 \% \mathrm{NK}$, and very close or superior to those of plants in the control treatment, irrigated with public-supply water and fertilized with $100 \%$ of the recommendation of mineral fertilizer, although differences were observed only for the variables leaf area, shoot fresh and dry matter (Table 3).

The mean values of leaf area (LA) and shoot fresh and dry matter (SFM and SDM) differed statistically for the studied treatments in ornamental sunflower, with significant reductions of SFM, SDM and LA in plants irrigated with TDS dilutions of 25,50 and $75 \%$ in comparison to those in the control treatment, irrigated with public-supply water (Table 3). These results may be due to the availability of nutrients to the plants, especially N, P and $\mathrm{K}$ present in the effluent in organic form, which might not have been sufficient to meet crop demands due to the dilution of TDS $(25,50$ and $75 \%$ ), since the fertilization recommendation for the crop was reduced by $50 \%$ in these treatments. However, sunflower plants irrigated with 100\% TDS and fertilized with $50 \%$ NK did not differ, regarding leaf area and shoot fresh and dry matter production (LA, SFM and SDM ), from those in the control treatment, irrigated with public-supply water (Table 3). Such better performance is probably due to the macro- and micronutrients dissolved at higher concentrations in the domestic effluent $(100 \%)$, corroborating inferences of other authors, who highlight the importance of using domestic wastewaters to supply nutrients and as a possibility of partial replacement of chemical fertilizers (REBOUÇAS et al., 2010; ANDRADE et al., 2012).

Other studies on the use of wastewater for sunflower irrigation found increment in shoot fresh and dry matter compared with control plants, irrigated with public-supply water. Among these studies, Souza et al. (2010) evaluated the cultivation of ornamental sunflower irrigated with wastewater and public-supply water, under four doses of earthworm humus, and observed that plants irrigated with wastewater showed higher accumulation of shoot fresh and dry matter compared with those irrigated with public-supply water. Nobre et al. (2009), studying sunflower cultivation, observed that, for every $20 \%$ water replacement with wastewater, there was an increment of $70.2 \%$ in shoot dry phytomass. 
Table 2. Summary of analysis of variance for plant height (PH), stem diameter (SD), number of leaves (NL), leaf area (LA), shoot fresh and dry matter (SFM and SDM), beginning of flowering (BF), full capitulum opening (FCO), capitulum internal and external diameter (CID and CED) and capitulum fresh and dry matter (CFM and CDM) of sunflower plants, cv. Anão de Jardim, irrigated with different dilutions of treated domestic sewage (TDS) with public supply water (PSW) at 22 and 37 days after transplanting (DAT) and at harvest. Cruz das Almas-BA, Brazil, 2016.

\begin{tabular}{|c|c|c|c|c|c|c|c|}
\hline \multirow{3}{*}{$\begin{array}{l}\text { Source of } \\
\text { variation }\end{array}$} & \multirow{3}{*}{ DF } & \multicolumn{6}{|c|}{ Mean square } \\
\hline & & \multicolumn{6}{|c|}{22 DAT } \\
\hline & & $\begin{array}{l}\text { PH } \\
(\mathrm{cm})\end{array}$ & $\begin{array}{c}\text { SD } \\
(\mathbf{m m})\end{array}$ & NL & $\begin{array}{c}\mathbf{L A} \\
\left(\mathbf{c m}^{2}\right)\end{array}$ & $\begin{array}{c}\text { SFM } \\
\text { (g) }\end{array}$ & $\begin{array}{c}\text { SDM } \\
\text { (g) }\end{array}$ \\
\hline TDS (\%) & 4 & $2.06^{\mathrm{ns}}$ & $0.49^{\text {ns }}$ & $1.67^{\mathrm{ns}}$ & $5797.94^{\mathrm{ns}}$ & $7.51^{\mathrm{ns}}$ & $0.08^{\text {ns }}$ \\
\hline Residual & 15 & 4.31 & 0.37 & 5.37 & 4897.73 & 9.44 & 0.13 \\
\hline C.V. $(\%)$ & & 23.49 & 11.64 & 21.45 & 43.38 & 44.82 & 44.85 \\
\hline \multirow{3}{*}{$\begin{array}{l}\text { Overall } \\
\text { mean }\end{array}$} & & 8.84 & 5.21 & 10.80 & 161.33 & 6.85 & 0.79 \\
\hline & & \multicolumn{6}{|c|}{37 DAT } \\
\hline & & $\begin{array}{c}\text { PH } \\
(\mathrm{cm})\end{array}$ & $\begin{array}{c}\text { SD } \\
(\mathrm{mm})\end{array}$ & NL & $\begin{array}{c}\text { LA } \\
\left(\mathbf{c m}^{2}\right)\end{array}$ & $\begin{array}{c}\text { SFM } \\
\text { (g) }\end{array}$ & $\begin{array}{c}\text { SDM } \\
\text { (g) }\end{array}$ \\
\hline TDS (\%) & 4 & $3.70^{\mathrm{ns}}$ & $0.79^{\text {ns }}$ & $5.07^{\mathrm{ns}}$ & $46024.57^{\text {ns }}$ & $97.93^{\text {ns }}$ & $1.10^{\mathrm{ns}}$ \\
\hline Residual & 15 & 32.67 & 0.57 & 9.50 & 30012.00 & 102.10 & 0.83 \\
\hline C.V. $(\%)$ & & 25.92 & 9.31 & 22.66 & 48.38 & 38.63 & 29.27 \\
\hline \multirow{3}{*}{$\begin{array}{l}\text { Overall } \\
\text { mean }\end{array}$} & & 22.05 & 8.09 & 13.60 & 358.09 & 26.16 & 3.11 \\
\hline & & \multicolumn{6}{|c|}{ HARVEST } \\
\hline & & $\begin{array}{l}\text { PH } \\
(\mathbf{c m})\end{array}$ & $\begin{array}{c}\text { SD } \\
(\mathrm{mm})\end{array}$ & $\mathbf{N L}$ & $\begin{array}{c}\mathbf{L A} \\
\left(\mathbf{c m}^{2}\right)\end{array}$ & $\begin{array}{c}\text { SFM } \\
\text { (g) }\end{array}$ & $\begin{array}{c}\text { SDM } \\
\text { (g) }\end{array}$ \\
\hline TDS (\%) & 4 & $84.21^{\mathrm{ns}}$ & $3.13^{\text {ns }}$ & $11.08^{\mathrm{ns}}$ & $458761.75^{\mathrm{ns}}$ & $1736.28^{\text {ns }}$ & $33.28^{\mathrm{ns}}$ \\
\hline Residual & 15 & 37.51 & 2.57 & 11.08 & 173563.68 & 676.38 & 13.63 \\
\hline C.V. (\%) & & 16.45 & 16.18 & 24.04 & 47.66 & 42.89 & 47.09 \\
\hline \multirow{2}{*}{$\begin{array}{l}\text { Overall } \\
\text { mean }\end{array}$} & & 37.23 & 9.90 & 13.85 & 874.12 & 60.64 & 7.84 \\
\hline & & $\begin{array}{c}\text { BF } \\
\text { (days) }\end{array}$ & $\begin{array}{c}\text { FCO } \\
\text { (days) }\end{array}$ & $\begin{array}{l}\text { CID } \\
(\mathrm{cm})\end{array}$ & $\begin{array}{l}\text { CED } \\
(\mathrm{cm})\end{array}$ & $\begin{array}{c}\text { CFM } \\
\text { (g) }\end{array}$ & $\begin{array}{c}\text { CDM } \\
(\mathrm{g})\end{array}$ \\
\hline TDS (\%) & 4 & $63.68^{\mathrm{ns}}$ & $68.93^{\mathrm{ns}}$ & $4.71^{\mathrm{ns}}$ & $2.57^{\mathrm{ns}}$ & $1315.90^{\mathrm{ns}}$ & $16.55^{\mathrm{ns}}$ \\
\hline Residual & 15 & 27.70 & 34.08 & 2.70 & 4.30 & 569.90 & 7.83 \\
\hline C.V. $(\%)$ & & 10.46 & 10.06 & 28.30 & 14.04 & 47.16 & 48.98 \\
\hline $\begin{array}{l}\text { Overall } \\
\text { mean }\end{array}$ & & 50.30 & 58.05 & 5.81 & 14.78 & 50.62 & 5.71 \\
\hline
\end{tabular}

Table 3. Mean values of leaf area (LA), shoot fresh and dry matter (SFM and SDM) of sunflower, cv. Anão de Jardim, irrigated with different dilutions of treated domestic sewage (TDS) effluent with public supply water (PSW), at harvest.

\begin{tabular}{cllr}
\hline Treatments & $\begin{array}{l}\text { LA } \\
\left(\mathbf{c m}^{2}\right)\end{array}$ & $\begin{array}{l}\text { SFM } \\
(\mathbf{g})\end{array}$ & \multicolumn{1}{c}{$\begin{array}{l}\text { SDM } \\
(\mathbf{g})\end{array}$} \\
\hline 0\% TDS + 100\% PSW + 100\% NK & $1337.29 \mathrm{a}$ & $86.96 \mathrm{a}$ & $11.39 \mathrm{a}$ \\
25\% TDS + 75\% PSW + 50\% NK & $586.48 \mathrm{~b}$ & $41.66 \mathrm{~b}$ & $5.47 \mathrm{~b}$ \\
$50 \% \mathrm{TDS}+50 \%$ PSW + 50\% NK & $662.39 \mathrm{~b}$ & $50.24 \mathrm{~b}$ & $6.52 \mathrm{~b}$ \\
$75 \% \mathrm{TDS}+25 \%$ PSW + 50\% NK & $651.38 \mathrm{~b}$ & $45.29 \mathrm{~b}$ & $5.32 \mathrm{~b}$ \\
$100 \%$ TDS + 0\% PSW + 50\% NK & $1133.07 \mathrm{a}$ & $79.06 \mathrm{a}$ & $10.49 \mathrm{a}$ \\
\hline
\end{tabular}

Cruz das Almas-BA, Brazil, 2016; Means followed by the same letters in the column do not differ by Scott-Knott test at 0.05 probability.

Although no significant difference was observed between the mean values of plant height $(\mathrm{PH})$, plants irrigated with $100 \%$ TDS showed higher $\mathrm{PH}$ compared with those of the other treatments (Table 4). Other researchers (SOUZA et al., 2010; ANDRADE et al., 2012; FREITAS et al., 2012) observed significant differences between mean $\mathrm{PH}$ values of sunflower plants irrigated with 
different types of water, obtaining increments of $\mathrm{PH}$ in plants irrigated with wastewater, in comparison to those irrigated with public-supply water. $\mathrm{PH}$ is a parameter of great importance for cut flower production, since a longer flower stem, combined with good quality and durability of the flowers, provides more options of use in ornamentation and decoration and, consequently, higher economic values of the product. Except for plants irrigated with $75 \%$ TDS, PH means were above $35 \mathrm{~cm}$ (Table 4), which according to Neves et al. (2009) is the minimum length a flower stem of ornamental sunflower must have to meet the high commercial standards.

Table 4. Mean values of plant height (PH), stem diameter (SD) and number of leaves (NL) of sunflower plants, cv. Anão de Jardim, irrigated with different dilutions of treated domestic sewage (TDS) effluent and public supply water (PSW).

\begin{tabular}{cccc}
\hline Treatments & $\begin{array}{c}\text { PH } \\
(\mathbf{c m})\end{array}$ & $\begin{array}{c}\text { SD } \\
(\mathbf{m m})\end{array}$ & NL \\
\hline 0\% TDS +100\% PSW + 100\% NK & $40.40 \mathrm{a}$ & $10.81 \mathrm{a}$ & $15.75 \mathrm{a}$ \\
25\% TDS + 75\% PSW + 50\% NK & $36.07 \mathrm{a}$ & $8.93 \mathrm{a}$ & $12.50 \mathrm{a}$ \\
$50 \%$ TDS + 50\% PSW + 50\% NK & $36.07 \mathrm{a}$ & $9.60 \mathrm{a}$ & $13.25 \mathrm{a}$ \\
$75 \%$ TDS + 25\% PSW + 50\% NK & $30.82 \mathrm{a}$ & $9.31 \mathrm{a}$ & $12.25 \mathrm{a}$ \\
$100 \%$ TDS + 0\% PSW + 50\% NK & $42.75 \mathrm{a}$ & $10.86 \mathrm{a}$ & $15.50 \mathrm{a}$ \\
\hline
\end{tabular}

Cruz das Almas-BA, Brazil, 2016; Means followed by the same letters in the column do not differ by Scott-Knott test at 0.05 probability level.

For stem diameter (SD) and number of leaves (NL), there were no statistical differences between the means (Table 4), corroborating the results found by Silva et al. (2012), who studied three sunflower cultivars ('IAC Uruguai', 'Helio 250' and 'Catissol') irrigated with dilutions of treated wastewater $(25,50,75$ and $100 \%)$, and also found no significant effect of the applied treatments on SD and NL mean values. On the other hand, Andrade et al. (2012) observed increment in SD and Freitas et al. (2012) observed higher mean values of SD and NL in sunflower plants, cv. 'Multissol', irrigated with wastewater, compared with plants irrigated with public-supply water.

According to Curti (2010), it is desirable that the flower stem have thicker diameter and be resistant, in order to support sunflower inflorescence, which generally is heavier than those of other cut flower species, such as gerbera and chrysanthemum. In the present study, regardless of treatment, SD mean values are within the interval from 5 to $15 \mathrm{~mm}$, established as quality standard for sunflower (GRIEVE; POSS, 2010) (Table 4). Regarding NL, although the main objective of ornamental sunflower cultivation is to sell flower stem, whose leaves are discarded in the preparation of the arrangements, it should be highlighted that this variable is of great importance during the growth stage and that the number and quality of leaves directly influence important physiological aspects such as photosynthesis (MACIEL et al., 2012), besides being rich in nutrients, serving as fodder for animal feed (PEREIRA et al., 2016).
Although there was no significant difference between the mean values of the treatments for sunflower growth variables, better performance was observed in plants subjected to $100 \%$ TDS in comparison to those irrigated with TDS dilutions of 25,50 and $75 \%$, which is probably due to higher availability of nutrients to plants, especially $\mathrm{N}$ present in the effluent, since this nutrient is the most limiting to sunflower production (BLAMEY; ZOLLINGER; SCHNEITER, 1997), causing yield reduction of up to $60 \%$ due to its deficiency (SMIDERLE, GIANLUPPI; GIANLUPPI, 2003). Prado and Leal (2006), studying nutritional deficiencies in the sunflower crop, found that $\mathrm{N}$ deficiency significantly reduced plant development, affecting the number of leaves, plant height, stem diameter and leaf area. In addition, wastewater contains $\mathrm{P}$ and $\mathrm{K}$, which also contribute to good plant development (SOUZA et al., 2010).

Beginning of flowering (BF) occurred, on average, at 50.3 DAT, and plants irrigated with $75 \%$ TDS were the first ones to begin flowering, on average at 45.5 DAT, with full capitulum opening (FCO) on average at 53.25 days. Although no significant differences were observed between the mean values of the treatments, plants irrigated with TDS dilutions required shorter period for $\mathrm{BF}$ and FCO (Table 5). Likewise, Souza et al. (2010), studying ornamental sunflower plants, observed that plants in the treatment irrigated with wastewater reduced the time for flower harvest by approximately 13 days compared with plants irrigated using public-supply water, demonstrating better characteristics for floriculture purposes. 
Table 5. Mean values of beginning of flowering (BF), full capitulum opening (FCO), capitulum internal (CID) and external diameter (CED) and capitulum fresh (CFM) and dry matter (CDM) of sunflower plants, cv. Anão de Jardim, irrigated with different dilutions of treated domestic sewage, at harvest;

\begin{tabular}{lcccccc}
\hline \multicolumn{1}{c}{ Treatments } & $\begin{array}{c}\text { BF } \\
\text { (days) }\end{array}$ & $\begin{array}{c}\text { FCO } \\
\text { (days) }\end{array}$ & $\begin{array}{c}\text { CID } \\
(\mathbf{c m})\end{array}$ & $\begin{array}{c}\text { CED } \\
(\mathbf{c m})\end{array}$ & $\begin{array}{c}\text { CFM } \\
(\mathbf{g})\end{array}$ & $\begin{array}{c}\text { CDM } \\
(\mathbf{g})\end{array}$ \\
\hline $0 \%$ TDS+100\% PSW+100\% NK & $54.75 \mathrm{a}$ & $62.75 \mathrm{a}$ & $7.25 \mathrm{a}$ & $15.30 \mathrm{a}$ & $74.64 \mathrm{a}$ & $8.20 \mathrm{a}$ \\
25\% TDS+75\% PSW+50\% NK & $47.75 \mathrm{a}$ & $55.50 \mathrm{a}$ & $5.32 \mathrm{a}$ & $14.32 \mathrm{a}$ & $43.06 \mathrm{a}$ & $4.81 \mathrm{a}$ \\
$50 \%$ TDS+50\% PSW+50\% NK & $49.50 \mathrm{a}$ & $56.75 \mathrm{a}$ & $4.92 \mathrm{a}$ & $14.25 \mathrm{a}$ & $37.45 \mathrm{a}$ & $4.24 \mathrm{a}$ \\
$75 \%$ TDS+25\% PSW+50\% NK & $45.50 \mathrm{a}$ & $53.25 \mathrm{a}$ & $4.87 \mathrm{a}$ & $14.07 \mathrm{a}$ & $33.12 \mathrm{a}$ & $3.73 \mathrm{a}$ \\
$100 \%$ TDS+0\% PSW+50\% NK & $54.00 \mathrm{a}$ & $62.00 \mathrm{a}$ & $6.67 \mathrm{a}$ & $15.92 \mathrm{a}$ & $64.84 \mathrm{a}$ & $7.57 \mathrm{a}$ \\
\hline
\end{tabular}

Cruz das Almas-BA, Brazil, 2016; Means followed by the same letters in the column do not differ by Scott-Knott test at 0.05 probability level.

Sunflower plants in the control treatment, irrigated with public-supply water and fertilized with $100 \%$ of the mineral fertilizer recommendation, showed a delay in BF, on average at 54.75 days (Table 5). Similar results were obtained by Oliveira et al. (2017) in sunflower plants, cv. Anão de Jardim, irrigated with different dilutions of wastewater. These authors found no significant difference between the mean values of the treatments for the variables $B F$ and FCO, which occurred on average at 49 and 52 days, respectively. Andrade et al. (2012), studying the production of four sunflower genotypes ('EMBRAPA 122/ V2000', 'Sol Noturno', 'Sol Vermelho' and 'Debilis Crème') irrigated with treated wastewater and public-supply water, also found no significant difference for the variables beginning of flowering and full capitulum opening.

The capitula showed no statistical difference regarding diameter (CID and CED) and mass (CFM and $\mathrm{CDM}$ ) between the different TDS dilutions. However, capitula in sunflower plants irrigated with $100 \%$ TDS were larger and more colorful, in comparison to those of plants irrigated with the other TDS dilutions $(25,50$ and $75 \%)$. Other studies have found statistical differences between the mean values, with increments in the variables CID and CED using wastewater, compared with public-supply water, in the ornamental sunflower plants (SOUZA et al., 2010; ANDRADE et al., 2012; FREITAS et al., 2012).

In general, capitulum external diameter (CED) in all treatments showed an acceptable mean value for the commercial standard, which according to Sakata Seed Corporation (2003) is between 10 and $15 \mathrm{~cm}$, and although there was no statistical difference, plants irrigated with $100 \%$ TDS had the highest CED $(15.92 \mathrm{~cm})$. Smiderle, Mourão and Gianluppi (2005), studying the behavior of 6 sunflower cultivars, observed that CED varied from 15.9 to $18.6 \mathrm{~cm}$. Silva et al. (2011) found mean CED of $18.06 \mathrm{~cm}$ in the cultivar 'Catissol 01' and 16.88 $\mathrm{cm}$ in the cultivar 'Embrapa - 122/V2000', whereas Freitas et al. (2012) observed mean overall CED of
14.62 and $16.05 \mathrm{~cm}$, obtained for well water and wastewater, respectively, in the cultivar 'Multissol'. These variations in capitulum diameter between genotypes or cultivars are normal and result from their intrinsic characteristics (CASTRO; FARIAS, 2005).

According to Souza et al. (2010), capitulum diameter is one of the most sensitive production components to the presence of $\mathrm{N}$, a macronutrient found at high concentration in the domestic effluent and responsible for increments in this variable at low doses. For Zagonel and Mundstock (1991), N acts in the critical stage of flower differentiation, affecting the number of achenes per capitulum and, consequently, capitulum diameter.

Regarding capitulum weight, the obtained results differ from those found by Souza et al. (2010), who observed increment of $204.88 \%$ in the capitulum dry phytomass of ornamental sunflower plants, cv. 'Embrapa BRS Oásis', irrigated with wastewater, in comparison to the treatment with public-supply water.

Although there were no significant differences between the mean values of the treatments for most growth and production variables evaluated, plants irrigated with $100 \%$ TDS and fertilized with $50 \%$ NK exhibited better development and production of capitula, in comparison to those irrigated with the highest TDS dilutions $(25,50$ and $75 \%$ ), and showed mean values very close to those of plants irrigated with public-supply water and fertilized with $100 \%$ of the mineral fertilization recommended for the crop. These results are consistent with those obtained in other studies regarding growth and production of ornamental sunflower irrigated with wastewater and make it possible to recommend the reuse of treated domestic sewage effluent for the crop, reinforcing the importance of exploiting the concentrations of nutrients (macro- and micronutrients) present in the wastewater, in such a way to partially replace mineral fertilization, favoring the saving of good-quality water and mineral fertilizers, besides promoting a destination for the effluent, avoiding inadequate 
disposal, with consequent contamination of water resources, and the saving with costs of treatment for this waste.

From the analysis of the results it can be concluded that it is possible to replace the supply water with treated domestic effluent for the irrigation of ornamental sunflower plants cv. Anão de Jardim in combination with a $50 \%$ reduction in the recommendation for mineral fertilization with nitrogen and potassium without damage to plant growth and production.

\section{ACKNOWLEDGMENTS}

To the Agricultural Engineering Graduate Program - PPGEA/UFRB and to the Coordination for the Improvement of Higher Education Personnel CAPES for providing the PNPD/CAPES grant to Karoline Santos Gonçalves Barreto.

RESUMO: O potencial hídrico e nutricional da água residuária vem sendo frequentemente explorado como fonte hídrica alternativa para irrigação de culturas, principalmente em regiões acometidas pela escassez de recursos hídricos. Desse modo, o objetivo deste trabalho foi avaliar o crescimento e a produção do girassol ornamental (Helianthuns annuus L.) cv. Anão de Jardim irrigado com diferentes diluições de efluente doméstico tratado em água de abastecimento. $\mathrm{O}$ experimento foi conduzido em delineamento experimental inteiramente casualizado com cinco tratamentos e quatro repetições, em casa de vegetação na área experimental do Programa de Pós-Graduação em Engenharia Agrícola, da Universidade Federal do Recôncavo da Bahia, localizada no munícipio de Cruz das Almas (BA). Os tratamentos foram iniciados sete dias após o transplantio das mudas e constituíram-se de cinco diluições de efluente doméstico tratado (EDT) com água de abastecimento (AA) (100\% AA - testemunha; 25\% EDT + 75\% AA; 50\% EDT + 50\% AA; 75\% EDT + 25\% AA e $100 \%$ EDT). No tratamento testemunha as plantas foram adubadas com $100 \%$ da recomendação de fertilizante mineral e nos tratamentos com efluente utilizou-se $50 \%$ da recomendação de nitrogênio e de potássio. Os indicadores biométricos (altura, diâmetro do caule, número de folhas, massa fresca e seca da parte aérea, área foliar) e de produção (diâmetro interno e externo do capítulo e massa fresca e seca do capítulo, início da floração e abertura total do capítulo) avaliados na colheita mostraram que as plantas de girassol ornamental irrigadas com 100\% do efluente apresentaram desempenho semelhante ao das plantas irrigadas com água de abastecimento, o que permite inferir sobre a possibilidade de substituição da água de abastecimento por efluente doméstico tratado para a irrigação juntamente com a redução de $50 \%$ da recomendação de adubação com nitrogênio e potássio sem prejuízos ao crescimento e produção das plantas de girassol ornamental cv. Anão de Jardim, resultando assim a economia de água de boa qualidade e de fertilizantes.

PALAVRAS-CHAVE: Helianthuns annuus L.. Água residuária. Recursos hídricos.

\section{REFERENCES}

ANDRADE, L. O. de; GHEYI, H. R.; NOBRE, R. G.; DIAS, N. da S.; NASCIMENTO, E. C. S. N. Qualidade de flores de girassóis ornamentais irrigados com águas residuária e de abastecimento. Idesia, Arica, v. 30, p. 19-27, 2012. https://doi.org/10.4067/S0718-34292012000200003

BLAMEY, F. P. C.; ZOLLINGER, R. K.; SCHNEITER, A. A. Sunflower production and culture. In: SEITEER, A. A. (Ed.). Sunflower technology and production. Madison: American Society of Agronomy, 1997. v. 1, Cap. 5, p. 595-670. https://doi.org/10.2134/agronmonogr35.c12

CASTIGLIONI, V. B. R.; BALLA, A.; CASTRO, C. de; SILVEIRA, J. M. Fases de desenvolvimento da planta de girassol. Londrina: EMBRAPA-CNPS, 1997. 26p.

CASTRO, C.; FARIAS, J. R. B. Ecofisiologia do girassol. In: LEITE, R. M. V. B. C.; BRIGHENTI, A. M.; CASTRO, C. (Ed.). Girassol no Brasil. Londrina: EMBRAPA, 2005. p. 163-218. 
CRUZ, M. P.; ANDRADE, L. O.; CRUZ, K. R. P.; PESSOA, A. M.; SOUZA, J. T. A.; SOARES, E. B. da S.; CARVALHO, M. G. de; ANDRADE JUNIOR, M. R. de. Crescimento do girassol ornamental submetido à substratos orgânicos em diferentes volumes de águas. Revista Scientia Agraria Paranaensis, Marechal Cândido Rondon, v. 15, n. 3, p. 312-319, 2016. https://doi.org/10.18188/1983-1471/sap.v15n3p312-319

CUBA, R. S., CARMO, J. R., SOUZA, C. F., BASTOS, R. G. Potencial de efluente de esgoto doméstico tratado como fonte de água e nutrientes no cultivo hidropônico de alface. Revista Ambiente \& Água, Taubaté, v. 10, n. 3, p. 75-585, 2015. http://dx.doi.org/10.4136/ambi-agua.1575

CURTI, G. L. Caracterização de cultivares de girassol ornamental semeados em diferentes épocas no Oeste Catarinense. 2010. 76 f. Dissertação (Mestrado em Agronomia) - Curso de Pós-Graduação em Agronomia, Universidade Tecnológica Federal do Paraná, Pato Branco, 2010.

D’ANGIOLELlA, G. L. B.; CASTRO NETO, M. T.; COELHO, E. F. Tendências climáticas para os Tabuleiros Costeiros da região de Cruz das Almas, Bahia. Revista Bahia Agrícola, Salvador, v. 4, p. 14-16, 2000.

FREITAS, C. A. S. de; SILVA, A. R. A. da; BEZERRA, F. M. L.; ANDRADE, R. R. de; MOTA, F. S. B.; AQUINO, B. F. de. Crescimento da cultura do girassol irrigado com diferentes tipos de água e adubação nitrogenada. Revista Brasileira de Engenharia Agrícola e Ambiental, Campina Grande, v. 16, n. 10, p. 1031-1039, 2012. https://doi.org/10.1590/S1415-43662012001000001

GRIEVE, C. M.; POSS, J. A. Response of ornamental sunflower cultivars 'Sunbeam' and 'Moonbright' to irrigation with saline wastewaters. Journal of Plant Nutrition, Philadelphia, v. 33, p. 1579-1592, 2010. https://doi.org/10.1080/01904167.2010.496883

HESPANHOL, I. A inexorabilidade do reúso potável direto. Revista DAE, Campinas, v. 63, n. 198, p. 63-82, 2015. https://doi.org/10.4322/dae.2014.141

MACIEL, P. M.; SOARES, T. M.; GHEYI. H. R.; REZENDE, E. P. L.; OLIVEIRA, G. X. S. Produção de girassol ornamental com uso de águas salobras em sistema hidropônico NFT. Revista Brasileira de Engenharia Agrícola e Ambiental, Campina Grande, v. 16, p. 162-165, 2012. https://doi.org/10.1590/S141543662012000200006

NEVES, M. B.; ANDRÉO, Y. de S.; WATANABE, A. A.; FAZIO, J. L. de; BOARO, C. S. F. Uso de daminozide na produção de girassol ornamental cultivados em vaso. Revista Eletrônica de Agronomia, Garça, v. 16, p. 31-37, 2009.

NOBRE, R. G.; GHEYI, H. R.; ANDRADE, L. O. de; SOARES, F. A. L.; NASCIMENTO, E. C. S. Crescimento do girassol irrigado com água residuária e adubação orgânica. Revista DAE, Campinas, v. 3, p. 50-60, 2009. https://doi.org/10.4322/dae.2014.037

NOVAIS, R. F., NEVES, J. C. L., BARROS, N. F. Ensaio em ambiente controlado. In: OLIVEIRA, A. J.; GARRIDO, W. E.; ARAÚJO, J. D.; LOURENÇO, S. (Ed.). Métodos de pesquisa em fertilidade do solo. Brasília: Embrapa-SEA, 1991. p. 189-253. Documentos.

OLIVEIRA, M. L. A.; PAZ, V. P. da S.; GONÇALVES, K. S.; OLIVEIRA, G. X. S. O. Crescimento e produção de girassol ornamental irrigado com diferentes lâminas e diluições de água residuária. Irriga, Botucatu, v. 22, n. 1, p. 204-219, 2017. https://doi.org/10.15809/irriga.2017v22n1p204-219

PEREIRA, D. R. M.; GODOY, M. M. de; SAMPAIO, C.C.; SILVA, T. V.; FELIX, M. J. D.; OLIVEIRA, R. L. R. de. Uso do girassol (Helianthus annuus) na alimentação animal: aspectos produtivos e nutricionais.

Veterinária e Zootecnia, Botucatu, v. 23, n. 2, p. 174-183, 2016. 
PRADO, R. de M.; LEAL, R. M. Desordens nutricionais por deficiência em girassol var. Catissol 01. Pesquisa Agropecuária Tropical, Goiânia, v. 36, n. 3, p. 187-193, 2006.

REBOUÇAS, J. R. L.; DIAS, N. da S.; GONZAGA, M. I. da S.; GHEYI, H. R.; SOUSA NETO, O. N. de. Crescimento do feijão-caupi irrigado com água residuária de esgoto doméstico tratado. Revista Caatinga, Mossoró, v. 23, p. 97-102, 2010.

SAKATA SEED CORPORATION. Sakata's reliable seeds: flower seed catalogue 2001-2003. Bragança Paulista: Sakata Sementes Agroflora, 2003. 99p.

SILVA, A. R. A. da; BEZERRA, F. M. L.; SOUSA, C. C. M. de; PEREIRA FILHO, J. V.; FREITAS, C. A. S. de. Desempenho de cultivares de girassol sob diferentes lâminas de irrigação no Vale do Curu, CE. Revista Ciência Agronômica, Fortaleza, v. 42, p. 57-64, 2011. https://doi.org/10.1590/S1806-66902011000100008

SILVA, L. T.; OLIVEIRA, M. L. A.; SACRAMENTO, D. S.; MENDONÇA, J. O.; OLIVEIRA, G. X. S.; GHEYI, H. R. Crescimento do girassol irrigado com água residuária tratada. In: INOVAGRI INTERNATIONAL MEETING e VI WINOTEC, 2012, Fortaleza. Anais... Fortaleza, 2012. 5p.

SMIDERLE, O. J.; GIANLUPPI, D.; GIANLUPPI, V. Adubação nitrogenada, espaçamento e épocas de semeadura de girassol nos Cerrados de Roraima. In: EMBRAPA. Resultados de pesquisa da EMBRAPA Soja, 2003. p. 33-39. (Documentos, 218).

SMIDERLE, O. J.; MOURÃO JÚNIOR, M.; GIANLUPPI, D. Avaliação de cultivares de girassol em savana de Roraima. Acta Amazônica, Manaus, v. 35, n. 3, p. 331-336, 2005. https://doi.org/10.1590/S004459672005000300004

SOUZA, R. M. de; NOBRE, R. G.; GHEYI, H. R.; DIAS, N. da S.; SOARES, F. A. L. Utilização de água residuária e de adubação orgânica no cultivo de girassol. Revista Caatinga, Mossoró, v. 233, n. 2, p. 125-133, 2010.

ZAGONEL, J.; MUNDSTOCK, C. M. Doses e épocas de aplicação de nitrogênio em cobertura em duas cultivares de girassol. Pesquisa Agropecuária Brasileira, Brasília, v. 26, p. 1487-1492, 1991.

ZOBIOLE, L. H. S.; CASTRO, C. de; OlivEIRA, F. A. de O.; OLIVEIRA JUNIOR, A. de. Marcha de absorção de macronutrientes na cultura do girassol. Revista Brasileira de Ciência do Solo, Viçosa, v. 34, p. 425-433, 2010. https://doi.org/10.1590/S0100-06832010000200016 